\title{
Education 2.0: Psycholinguistic Analysis
}

\section{Освіта 2.0: психолінгвістичний аналіз}

\section{Olena Goroshko ${ }^{1}$}

HabDoc in Philology and Sociology, Professor, Chairholder of CrossCultural and Foreign Languages

Department

\section{Олена Горошко ${ }^{1}$}

доктор філологічних наук, доктор соціологічних наук, професор, завідувач кафедри міжкультурної комунікації та іноземної мови

E-mail: olena_goroshko@yahoo.com orcid.org/0000-0002-8592-1022

\section{Tetiana Poliakova ${ }^{2}$}

Ph.D. in Philology, Associate

Professor, Chairholder of the

Department of Language Training
Тетяна Полякова ${ }^{2}$

кандидат філологічних наук, доцент, завідувач кафедри мовної підготовки

\section{E-mail: tatyana kharkov@outlook.com} orcid.org/0000-0002-3353-2228

${ }^{1}$ National Technical University «Kharkiv Polytechnic Institute» 2, Kirpichov Str., Kharkiv, Ukraine, 61000

${ }^{2}$ Kharkiv Petro Vasylenko National Technical University of Agriculture 44, Alchevsky Str., Kharkiv, Ukraine, 61002
${ }^{1}$ Національний технічний університет «Харківський політехнічний інститут» $\checkmark$ вул. Кирпичова, 2, Харків, Україна, 61000

${ }^{2}$ Харківський національний технічний університет сільського господарства імені П. Василенка $\triangle$ вул. Алчевських, 44, Харків, Україна, 61002

Original manuscript received August 25, 2018

Revised manuscript accepted May 20, 2019 


\begin{abstract}
Introduction. The article presents the results of the investigation of the impact of new information and communication technologies, namely Internet technologies of the social web, on the linguistic consciousness in the learning environment. The term covers a certain concept of the Global Web development, when the main functional task of a web service is aimed at maintaining interaction between network users.

The method of a free and directional associative experiment was chosen as main research technique. It allows most accurately identifying the meaning of the word, seeing what is behind this word in the linguistic consciousness of a person. Associative series were identified for a number of concepts - the most popular social web services and Internet technologies (Internet, Instagram, social media, communication, Twitter, Telegram, WhatsApp, Youtube, Pinterest, Google, selfie).

Results. The associative experiment showed that information, communicative and functional components of the Global net are actualized in the linguistic consciousness of the participants of the educational process most of all. Almost all social media services have both positive and negative connotations. The educational component of social media has been marked little, if at all, in the linguistic consciousness of the recipients which indirectly indicates that their use in the educational process has not become an institutional practice yet.

Conclusions. The results of the research will contribute to the development of a new direction in modern linguistics - psycholinguistics 2.0 which studies psychological and linguistic aspects of human speech in social media, social and psychological aspects of using language in speech communication using web 2.0 platforms and services, and in individual verbal and thinking activity. The study is characterized by an interdisciplinary nature, being at the interface of psycholinguistics 2.0 and education 2.0, which contributes to a better understanding of the polyparadigmatic way of the development of humanitarian knowledge under the influence of technologies in general.
\end{abstract}

Key words: education 2.0, psycholinguistics 2.0, social web, Internet technologies, free associative experiment.

\title{
Вступ
}

У даній роботі розглядається вплив нових комунікативних технологій на мовну свідомість в освітньому середовищі. У якості основної дослідницької методики були задіяні методи вільних і спрямованих асоціацій, які найбільш ефективно показують зріз мовної свідомості, тобто те, що в людини переховується в розумінні того чи іншого поняття чи явища, певний соціальний зміст, який наповнює ці поняття (Уфимцева, 2000).

Зауважимо, що інформаційно-комунікативні технології стрімко змінюють наше життя, впливаючи на всі соціальні 
практики в бізнесі, науці, культурі, освіті. Особливо помітно це стало 3 поширенням інтернет-технологій соціального вебу, під якими розуміють певну концепцію розвитку Глобальної павутини, коли основне функціональне завдання веб-сервісу спрямоване на підтримку взаємодії між користувачами мережі.

Що таке соціальний веб? Це саме ті веб-сервіси й платформи, функціонування яких визначається відносинами і взаємодіями, які люди здійснюють через Інтернет, тобто програмне забезпечення, обладнання та системи, які розроблені, створені й запущені для підтримки цієї взаємодії.

Необхідно зауважити, що, коли ми говоримо про взаємодію людей в Інтернеті, ми не просто говоримо про обмін контентом або повідомленнями. Такі сервіси соціального вебу, як Facebook, Twitter, LinkedIn, Pinterest, Instagram та інші, забезпечують як гігантський трафік інформаційного обміну між користувачами, так і безперервний зв〉язок практично в режимі «нон-стоп» без певної прив〉язки до тимчасово-просторового параметру. Згідно 3 дослідженням, проведеним Pew Research, понад 81,0\% всіх дорослих американців (18 років і старше) користуються Інтернетом (Perrin \& Anderson, 2019). А дослідження Internet World Stats, проведене в глобальному масштабі, повідомляє, що більше 4383810342 особи у всьому світі мають доступ до Інтернету - в порівнянні з 394 мільйонами у 2000 році (Internet World Stats, 2019). Більш того, проникнення користувачів мобільного інтернету склало в 2013 році 73,4\%. А до березня 2019 року проникнення Інтернету в світі в цілому склало 56,8\% 3 провідним мобільним підключенням (Internet. Statistics and Market Data about the Internet, 2019).

Експерти стверджують, що комп>ютери подвоюють свої технічні можливості кожні 12-18 місяців. Технологічний сектор зараз у мільйон разів більш сучасний, ніж був у 2000 році, що змушує людство швидко адаптуватися в інформаційному суспільстві, включаючи сучасну освіту (How tech and social media..., 2018). Це стрімке соціальне зрушення в комунікаціях змусило глобальних постачальників освітніх послуг відреагувати на ці зміни (How tech and social media..., 2018). У 2010-х роках з'являється термін освіта 2.0, що описує освітні процеси й практики, що відбуваються за допомогою сервісів другого вебу (Evans \& Nygaard, 2019; Образование 2.0.., 2017). Цей освітній формат функціонує на 
принципах інтерактивної взаємодії між контентом і користувачем, а також між самими користувачами, коли вони переходять від простого доступу до інформації, до стану взаємодії з контентом за допомогою коментарів, реміксів та інших можливостей, що надаються функціоналом цих технологій. Освіта 2.0 включає в себе більш тісні взаємодії між викладачем і студентом, між самими студентами, між студентами й контентом. Уважається, що основний принцип освіти 2.0 можна описати за допомогою трьох Cs (англ. communication (спілкування), connection (зв'язок) і collaboration (співробітництво)) (Preparing 21st Century Students for a Global Society, 2012; Tîrziua \& Vrabie, 2015). Зазвичай освіта $2.0 €$ додатковим форматом до традиційної моделі навчання (віч-на-віч), покращуючи дану модель. При цьому власне традиційна модель не надто трансформується, хоча основа для такої трансформації вже закладена (Keats \& Schmidt, 2007).

Зауважимо також, що зростання як кількості цифрових пристроїв, так і людей, що володіють технологіями їх використання (Demirdag, 2016), постійно збільшується, а такі сервіси соціального вебу як Facebook, Twitter, Instagram та інші формують новий тип інформаційного суспільства - гіперконтактне, глобалізоване співтовариство, відкриваючи все нові ідеї та концепції простим натисканням кнопки. I поступово наш світ перетворюється на живу, дихаючу соціальну мережу, яка розширює можливості освіти, виводячи іiі за межі традиційного навчання в область спільного віртуального навчання протягом усього життя. З'являються такі освітні технології, як змішане навчання, перевернутий клас, мобільний, співтовариство комунікативних практик, навчання 2.0 і деякі інші.

Використання сервісів соціального вебу, включаючи соціальні мережі, поступово стає дуже важливою частиною нашого життя. Опитування, проведене в 2018 році, показало, що найбільш поширеною інтернет-діяльністю серед молодих людей у віці від 15 до 24 років стало використання соціальних мереж. I якщо студенти добре розбираються в інструментах інформаційних і комунікаційних технологій, то було б нелогічно, якби викладачі не використовували ïx для залучення учнів в освітній процес: вони можуть і повинні творчо інтегрувати інструменти ІКТ у викладання, щоб створити мультимодальне онлайнове середовище навчання. Це буде 
виховувати в учнів ключові компетенції, необхідні для досягнення успіху в технологічно орієнтованому світі XXI століття (Jones, Jo \& Philippe, 2007; Hussain, 2012).

Було встановлено також, що практики використання соціального вебу в освіті полегшують вивчення мови й розвивають критичне мислення, заохочують соціальний конструктивізм i дозволяють як самостійне, так i спільне навчання в різних галузях знань (Davis, 2018; How tech and social media ..., 2018; Liu \& Ko, 2019).

Власне розвиток освітніх концепцій у наш час направлено на вдосконалення технологій, що зміцнюють довіру, прозорість i забезпечують ефективну інтеграцію різних навчальних засобів i середовищ.

Отже, метою даного дослідження $є$ аналіз впливу нових інформаційно-комунікативних технологій, а саме інтернеттехнологій соціального вебу, на мовну свідомість в освітньому середовищі.

Об’єктом дослідження стали освітні практики з використанням соціального вебу (освіти 2.0), а його предметом - відображення їх у мовній свідомості його основних стейкхолдерів (учасників).

\section{Методи і методики дослідження}

В якості основного способу дослідження було обрано метод вільного й спрямованого асоціативного експерименту, а цільовою аудиторією (інформантами) були обрані студенти й викладачі вузів. Методика вільного і спрямованого асоціювання була використана в силу того, що вона найбільш точно дозволяє виявити значення поняття, що саме стоїть за цим словом у мовній свідомості людини. Ця методика іноді найбільш точно дозволяє показати й ті приховані соціальні смисли, які неможливо встановити за допомогою іншої методології (проведення опитувань, анкетування або ж фокус-груп) (Горошко, 2005). Експеримент проходив у режимі «онлайн» у два етапи. Спочатку учасникам пропонувалося відповісти першим словом, яке спало на думку, на ряд понять - найбільш популярних сервісів соціального вебу та інтернет-технологій (Інтернет, Інстаграм, соціальні медіа, комунікація, Твіттер, Телеграм, BamсAn, 
Ютуб, Пінтрест, Гугл, Селфі, Фейсбук), а потім вони повинні були завершити (дописати) речення, які також містили ті ж самі поняття соціального вебу: "Пінтрест - ие частина ...», "Ютуб - я там як ...», "ВатсАп-спілкування - ие ...», «Телеграм - без нього не ...», «Гуал - ие частина ...», "Селфі - це для мене як ...», "Фейсбук це те, щио мені ...», "Інстаграм мені потрібен ...», «Твіттер я використовую для ...», "Соціальні медіа для мене перш за все це ...», «Комунікація - ие те, щэо ...», «Інтернет я бачу як ...».

Усього в експерименті взяло участь 150 викладачів i 179 студентів гуманітарних i технічних спеціальностей. Рідна мова інформантів була російська i/aбо українська. Експеримент проводився російською мовою.

Зібрані нами асоціативні поля реакцій були впорядковані за частотою та алфавітом.

Ми наводимо змішаний аналіз сприйняття від двох цільових груп - студентів і викладачів університетів (у подальшому планується також порівняти отримані асоціативні поля від викладачів і студентів). Асоціативний експеримент здійснювався в режимі онлайн. Планується також аналогічний експеримент провести і в оффлайні, щоб перевірити валідність його результатів i зрозуміти, чи впливає спосіб проведення (онлайн і оффлайн) i тип використовуваної методології (вільне володіння і спрямований асоціативний експеримент) на одержувані дані, що сприятиме вдосконаленню, на наш погляд, такого нового напряму в сучасній лінгвістиці, як психолінгвістика 2.0.

\section{Результати та дискусії}

Психолінгвістика 2.0 вивчає психологічні та лінгвістичні аспекти мовної діяльності людини в соціальних медіа, соціальні й психологічні аспекти використання мови в процесах мовленнєвої комунікації за допомогою платформ і сервісів веб 2.0 індивідуальної мислемовної діяльності (Леонтьев, 1989, 2003). Предметом дослідження психолінгвістики 2.0 є перш за все мовленнєва діяльність як специфічно людський вид діяльності, іiї психологічний зміст, структура, види (способи), у яких вона здійснюється, форми, у яких вона реалізується, виконувані нею функції. I якщо предметом 
психолінгвістики (Altmann, 2002; Harley, 2005; Traxler \& Gernsbacher, 2006; Trevisan \& Garcia, 2019) є «мовленнєва діяльність як ціле i закономірності іiі комплексного моделювання» (Леонтьев, 2003: 120), то предметом психолінгвістики $2.0 є$ мовленнєва діяльність в середовищі соціальних медіа і закономірності іiі комплексного моделювання в даному середовищі. Підкреслимо також, що іншим найважливішим предметом вивчення психолінгвістики 2.0 виступає мова як основний засіб здійснення мовленнєвої та індивідуальної мислемовної діяльності, функції основних знаків мови в процесах мовної комунікації 2.0 (тобто комунікативних процесах, що відбуваються за допомогою сервісів соціальних медіа). Цікаво, що в одній зі своїх робіт останнього періоду О.О. Леонтьєв указує, що метою психолінгвістики $\epsilon$ «... розгляд особливостей роботи механізмів породження і сприйняття мови в зв'язку з функціями мовленнєвої діяльності в суспільстві і з розвитком особистості» (Леонтьев, 2003: 298). У зв'язку з цим предметом психолінгвістики «... $є$ структура процесів мовотворення i мовосприйняття в їх співвідношенні зі структурою мови» (Леонтьев, 2003: 144). Звідси випливає, що предметом психолінгвістики 2.0 є це ж співвідношення між процесами мовотворення і мовосприйняття, тільки обмежені мовним середовищем соціальних медіа. I тут фокус досліджень буде спрямований перш за все на аналіз мовної здатності людини стосовно мовленнєвої діяльності в соціальних медіа, з одного боку, і до системи мови - 3 іншого. Підкреслимо також, що будь-якого одного, загальноприйнятого визначення предмета дослідження психолінгвістики у вітчизняній і зарубіжній науці досі немає; у різних напрямках і школах психолінгвістики він визначається по-різному. Виходячи з узагальненого визначення предмета психолінгвістики, запропонованого О.О. Леонтьєвим (власне одним із засновників психолінгвістики в СРСР), «предметом психолінгвістики $є$ співвідношення особистості зі структурою i функціями мовленнєвої діяльності, 3 одного боку, і мовою як головною «складовою творення» образу світу людини - 3 іншого» (Леонтьев, 2003: 19), метою вивчення психолінгвістики 2.0 повинен стати образ світу людини в соціальних медіа - у новій техномовній формації, породженій технологіями веб 2.0.

Отже, результати проведеного вільного асоціативного експерименту показали таку картину. 
«Інтернет» мислиться як «інформація - 100, мережа - 72, спілкування -53 , зв'язок -18 , «-» - 7, Інстаграм -7 , свобода -6 , пора на пенсію -5 , соціальні мережі -5 , безмежний -5 , Браузер Google -4 , телефон -4 , знання -3 , мій немає -3 , ноутбук -3 , смітник -3 , робота -3 , можливість -2 , час -2 , павутина -2 , планета -2 , провід -2 , простір - 2, світ -2 , амазон, Вайбер, смс, відео з котиками, Вікіпедія, Вконтакті, люди, мій, лист, відкритий доступ, звалище ідей, Телеграм, хороша бібліотека, людина».

Ми бачимо, що «Інтернет» найбільше асоціюється 3 інформаиією і спілкуванням, це - зв'язок, соиіальні мережі, свобода і він безмежний. Це знання і можливість, телефон, робота. Цікаво, що часто він не викликає реакцій узагалі, він не потрібен і пора на nенсію. Таким чином, інформаційна, комунікативна і функціональна складова Глобальної мережі найбільше актуалізована в мовній свідомості інформантів - учасників освітнього процесу.

На «соціальні медіа» ми зібрали такі реакції: «« - »- 67, спілкування -65 , інформація -53 , телебачення -39 , реклама -8 , новини -7 , Фейсбук -6 , Інстаграм - 5, пропаганда -5 , пора на пенсію - 5, соціальні мережі - 5, люди -4 , 3MI -4 , Youtube -3 , смітник -3 , розважальний контент -3 , Телеграм -3 , марення -2 , відеоконтент -2 , спосіб спілкування -2 , вибір -2 , інтернет -2 , контакт -2 , меми -2 , думки -2 , музика -2 , політика -2 , сфера діяльності - 2, тусовка -2 , фото - 2, аккаунт, бардак, можливості, Вконтакті, газета, зомбі, інтерактивний, інтерес, канал, картинка, неправда, нічого, освіта, однокласники, просування, репортаж, звалище ідей, яскравість».

Аналіз асоціативного ядра на цей стимул показує, що цей термін не дуже знайомий інформантам (на першому місці за частотою стоїть відмова від реагування), а якщо відомий, то найбільше соціальні медіа уявляють як спілкування, тусовку, інформачію, телебачення, рекламу, новини і пропаганду. Їх також асоціюють 3 соціальними мережами, а також 3 конкретними сервісами соціальних медіа, такими як Фейсбук, Інстаграм, Телеграм або Ютуб. У даному асоціативному полі зустрічаються i негативні реакції: неправда, нічого, звалище ідей, марення, смітник, що свідчить про неоднозначність сприйняття даного поняття. При цьому інформаційна функція тут виходить на перший план, соціальні медіа виступають як $3 M I$ або як певна їх альтернатива. 
Реакції на стимул «комунікація» вийшли такими: «спілкування - 93, телефон - 60, зв’язок - 42, люди - 36, Телеграм - 21, друзі - 5, пора на пенсію - 5, «-» - 5, мережі 4 , час -3 , телебачення - 3, передача інформації - 3, розуміння 3, прогулянка - 3, взаємодія - 2, можливість - 2, життя - 2, Телеграм - 2, інтернет - 2, суспільство - 2, листування - 2 , розвиток - 2, робота - 2, розмова - 2, е-mail, Вконтакті, бізнес, Джиро, діалог, завод Комунар, Інстаграм, дзвінок, контакт, круто, масова, організованість, викладач, програма, реклама, звалище ідей, засіб, суперечка, суть соціального, втома, чат, емоції, це».

Як видно 3 наведених асоціацій, «комунікація» мислиться, перш за все, як спілкування, розуміння, зв'язок і телефон. Вона дуже олюднена - це люди, друзі, взаємодія, листування, розвиток i передача інформаціï. В основному вона сприймається як щось позитивне: засіб, суперечка, суть соціального. Негативних реакцій у полі майже не зустрічається або вони одиничні: утома, звалищзе ідей.

На стимул «Фейсбук» було отримано таке асоціативне поле: ««-» - 69, новини - 61, спілкування - 56, соціальна мережа - 39, незрозуміло - 20, пора на пенсію - 5, родичі -5 , синій $-5, \mathrm{~F}-4$, друзі - 4, інформація - 4, не потрібен - 4, політика - 4, робота 4, складно - 4, старість - 4, Цукерберг - 4, марна штука - 3, марення -3 , ігри -3 , іноземці -3 , смітник -3 , пости -3 , мережа 3 , бізнес -2 , гроші -2 , інтерес -2 , пошук -2 , реклама -2 , тексти 2, арбітраж, блог, більше, група, дискомфорт, старовина, життя, зал публічної бібліотеки, забутий, логін, мій світ, думки, сміття, треба, незручності, президент, звичка, просвіта, професіонал, публікації, репост, самовираження, сайт, нудно, 3МI, дивні співрозмовники, фотографіï, читання».

У даному асоціативному полі вражає перш за все кількість відмов від реагування i велика кількість негативно забарвлених реакцій - смітник, складно, старість, марна итука, дискомфорт, іноземці, старовина, марення, дивні співрозмовники і сміття. Найпопулярніша соціальна мережа світу бачиться описово через іiі дизайн: як $F$ і синя. Цю мережу пов'язують найбільше з новинами, спілкуванням, політикою, інформацією і друзями. Зустрічаються й реакції з семантичної групи освіта, але вони поодинокі: просвіта, професіонал, публікації. 
На іменник «Твіттер» було складено наступне асоціативне поле: «пташка - 71,«-» - 67, соціальна мережа - 66, пост - 21, не користуюся - 20, спілкування - 5, думки - 5, пора на пенсію 5 , вираження думок -4 , стислість -4 , твітти -4 , новини -3 , повідомлення -3 , блог - 2 , месенджер -2 , розвага -2 , свист 2 , цитата -2 , чат - 2, анекдоти, марно, базіка, нерозумно, голос, щоденник, ділитися, дошка оголошень, життя, залежність, навіщо, Ілон Маск, зірки, Інстаграм, книга, меми, мене немає, сміттєвий бак, не цікаво, не розумію, нові знайомства, нестача часу, щось застаріле, смітник ідей, рідний, репост, свобода, нудно, складність, спам, суперечки, твістер, США, Трамп, текст, трансляції, Фейсбук, фото, юність».

За отриманими реакціями стає зрозумілим, що Твіттер асоціюється 3 його графічним символом - пташкою. Однак у багатьох він ні $з$ чим не асоціюється (судячи 3 кількості отриманих відмов), що побічно вказує на те, що інформанти або не користуються цим сервісом або взагалі про нього нічого не знають. Багато опитаних інформантів ним узагалі не користуються. Також його визначають найбільше як соціальну мережу, спілкування, блог і месенджер; він пов'язаний з постами або твітами, новинами, анекдотами тощо. В асоціативному полі зустрічається й багато негативних реакцій: нудно, складність, спам, залежність, марно, базіка, нерозумно, не розумію, нестача часу, щзось застаріле, смітник ідей.

Асоціативне поле на іменник «Інстаграм» було наступним: «фотографії - 84,«-» - 63, показуха - 60, картинки - 25, пора на пенсію - 25, дурість - 6, лайки - 4, стрічка - 4, розвага - 4, мережа 4 , друзі -3 , блог -2 , блогер -2 , життя - 2 , іконка Інстаграма 2 , спілкування - 2, популярність -2 , подорожі -2 , реклама -2 , торгівля - 2, Селфі - 2, естетика - 2, альтернатива, богема (після цензури), відео, час, дозвілля, залежність, заробіток, заздрість, цікаво, історії, якість, меми, мода, смітник, обман, відпочинок, навчання, послідовники, смітник образотворчого мистецтва, пост, профіль, надто просте, сторіз, телефон, електронна рамка».

3 наведеного асоціативного поля видно, що сервіс Інстаграм найбільше пов>язаний 3 фотографіями і марнославством (реакція «показуха» має досить високий показник частотності, проте для багатьох він або не знайомий, або викликає негативну 
реакцію (судячи 3 кількості відмов (друга позиція за частотністю в асоціативному полі)). В асоціативному полі зустрічається багато негативних реакцій і крім відмов: залежність, заздрість, смітник, обман, смітник образотворчого мистецтва. Однак цей сервіс асоціюється і з спілкуванням, часом, дозвіллям, розвагою, заробітком тощо. У багатьох реципієнтів Інстаграм асоціюється через його функціонал: мережа, блог, друзі, реклама, селфi, лайки. Та Інстаграм - це естетика.

На слово «селфі» наші інформанти відреагували таким чином: «фото - 74, «-»-64, дівчата -43 , обличчя - 21, камера 18 , палиця - 18, краса - 7, дзеркало - 5, пора на пенсію - 5, самоствердження - 5, телефон - 5, марення - 3, спогад - 3, дурість -3 , моменти -3 , втіха -3 , я -3 , Інстаграм - 2, друзі 2 , любов до себе -2 , багато фото -2 , море -2 , немає -2 , трата часу - 2, посмішка - 2, фотографія - 2, автопортрет, хвороба, маячня, випендрьож, гламур, смуток, губи, забава, як життя, комплекси, лайки, люблю селфі, настрій, непотрібна річ, буденність, самотність, вікно, показуха, пам'ять, прикол, проти, ракурс, своя фотографія, дивно, сором, фальшивість, фотошоп, емоція».

Отже, слово «селфі» сприймається як фото, дівчата, особа, фотокамера, палиия, краса, дзеркало. Досить багато було отримано на цей іменник і відмов (за частотою вони стоять на другому місці). У цілому, «селфі» визначається і позитивно (про що свідчать реакції люблю селфі, настрій, втіха, забава, самоствердження, спогад, друзі), і негативно (буденність, самотність, трата часу, показуха, хвороба, марення, випендрьож, гламур, дивно, сором, фальшивість). Але перш за все «селфі»- це фото і фотопортрет, а також - емоція.

На «Гугл» ми отримали таке поле асоціацій: «пошуковик 94, допомога - 69, інформація - 36, відповідь - 35, Гугл - 25, знання -6 , пошук -6 , перекладач -5 , пора на пенсію -5 , 1 i 100 нулів» -3 , гігант -3 , запит -3 , пошта -3 , бібліотека -2 , браузер -2 , всезнаючий -2 , корпорація -2 , любов -2 , навчання 2, «-» - 2, швидко, геніально, гул (гул бджолиний - шум), докс, дудли, джерело знань і сміття одночасно, карта, мій учитель, знайде все, нейромережа, непогано, погода, привіт, резерв, угу! (голос птиці пугача), порятунок, розум, фінанси, Хром, шпаргалка, енциклопедія, «+»»». 
За наведеними реакціями на іменник «Гугл» ми розуміємо, що Гугл сприймається виходячи з його функціоналу: це пошуковик, допомога, інформачія, відповідь, знання, перекладач, гігант і запит. Це швидко і геніально, і Гугл - це Гугл. Негативних реакцій у його асоціативному полі практично не фіксується, виняток становлять лише пора на пенсію та джерело знання $i$ сміття одночасно. Цей сервіс також асоціюється через його прагматичну і функціональну спрямованість, про що свідчать реакції навчання, всезнаючий, порятунок, шпаргалка, енциклопедія. Зауважимо, що саме цей стимул був мало не єдиним, який викликав реакції, пов'язані 3 навчальним процесом - мій учитель, навчання.

Месенджер «Телеграм» дав наступне асоціативне поле: «спілкування - 90, «-» - 85, повідомлення - 30, листування - 25, канал - 6, кращий месенджер - 6, зручно - 6, не цікавлюсь - 5, новини - 5, пора на пенсію - 5, чат -5 , друзі - 4, лист -3 , літачок 3 , Вконтакті -2 , Дуров -2 , групи -2 , значок -2 , інформація -2 , комунікація - 2, музика - 2 , простота -2 , свобода -2 , зв'язок 2, анонімність, ансамбль, безпека, чудовий, вайбер, відео, головна соціальна мережа, голос, дискорд, діти, запасний варіант, захист і швидкість і стабільність, заборонене, комфортно, сходи в бібліотеці, машина, мемасікі, моє життя, оперативність, підозріло, розвиток, розмови, стікер, соціальна мережа, телеграма, текст, телеграмммм, файл, телепрограма, телефон, це життя».

Ми бачимо, що «Телеграм» пов'язаний із спілкуванням, повідомленнями, листуванням і новинами. Це - інформаџія i комунікація, розмови, розвиток, канал і кращий месенджер, і це просто зручно, комфортно, це - оперативність і це - життя, а також захист $i$ швидкість $i$ стабільність. Він асоціюється 3 його засновником і корпоративною символікою - реакції Дуров i літачок. Також в асоціативному полі зустрічається багато реакцій зі сфери ІКТ - файл, вайбер, відео, Вконтакті, чат, групи, текст, сои. мережа. Однак деякі його не знають або негативно ставляться 95 відмов від реагування, в асоціативному полі реєструються також реакції - не цікавлюся, не знаю і це підозріло.

На аналогічний Телеграму месенджер «ВатсАп» ми отримали такі реакції: ««-» - 145, месенджер - 49, спілкування - 39, дзвінки 8 , зелений -7 , не користуюся - 6, листування - 5, пора на пенсію 5 , повідомлення -5 , не знаю -4 , відеозв'язок -3 , родичі -3 , 
сім'я - 3, телефон - 3, чат -3 , іконка ват сапа -2 , Телеграм - 2, формальність - 2, що це? - 2, Iрhone, ватсап, безкоштовно, вайбер, питання, Віра Миколаївна, захищеність, діалог, друзі, знайомства, $\epsilon$, камера, картинки, хтось там ще сидить?, сміття, місце для тих, кому за 40, на пару хвилин, нічого, нудно, номера, листівки, перші голосові повідомлення, популярніше за кордоном, користь, рідко, робота, минуле, зв'язок, соц. мережа, видалити, зручно, фотки, шифр».

Найперший висновок за наведеними асоціаціям - цей сервіс $\epsilon$ практично невідомим більшості інформантів (кількість відмов від реагування вкрай висока (145)). Він також визначається як месенджер, це - спілкування, і повідомлення, і відеозв'язок. Це телефон, діалог і зв'язок. Він пов'язаний з сім'єю та родичами, друзями і знайомствами. Він також асоціюється через функціонал: відеозв'язок, зелений, чат, телефон, захищеність, популярніше за кордоном. Також, як і Телеграм, він асоціюється зі словами 3 семантичного кластера IКT - шифр, сои. мережа, вайбер, захищеність, Iphone. I він викликає неоднозначну реакцію (як позитивну - користь, безкоштовно, зручно, так і негативну - нічого, нудно, сміття, на пару хвилин, хтось там щуе сидить?, місие для тих кому за 40).

На іменник «Ютуб» були отримані такі реакції: «відео 98 , блог - 55, музика - 35, пора на пенсію - 34, розвага -25 , відпочинок - 14, смітник - 4, серіал -4 , смішно - 4, фільми - 4, блогери -3 , дозвілля -3 , цікаве відео -3 , інформація -2 , стрічка 2 , багато корисного - 2, реклама - 2, «+», «-», англійська, відео, інтерв’ю, бачив, говорилка, нерозумно, запити, гроші, зомбі, іноді, іконка ютуба, цікаві телепередачі, зіпсувався, канал, найкраща річ в інтернеті, світ, поїхали, освітні відео, корисно, перегляд, розвиток, звалище ідей у форматі ідей, набрід ідіотів і улюблених пісень, соціальний майданчик, щастя, туб, телевізор багатоканальний, творчий майданчик, убивство часу, тумблер, утопія шоу, харашо!, шоу».

За асоціативним полем, отриманим на одному 3 найпопулярніших сервісів соціальних медіа - каналу Ютуб, ми бачимо, що він визначається як відео, блог, стрічка, він пов'язаний 3 музикою, інформачією, дозвіллям, відпочинком, фільмами та розвагами. Там багато корисного і реклами. С освітні відео. Він також 
забарвлений як в позитивні (багато корисного, цікаві телепередачі, щастя, найкраща річ в інтернеті, корисно), так і негативні тони (убивство часу, звалище ідей у форматі ідей, набрід ідіотів, говорилка, нерозумно, зомбі, зіпсувався). I він також асоціюється через свій функціонал: відео, громі, соиіальний майданчик, улюблені пісні, перегляд, запити, інтерв'ю, тумблер, канал.

Соціальна мережа «Пінтрест» дала такий асоціативний ряд: ««-» - 225, картинки - 12, не знаю - 11, натхнення -7 , що це? 7, пора на пенсію - 5, фото - 5, арт - 4, колекція (зображень) 4 , видимість - 3, ідеї - 3, краса - 2, мода - 2, програма - 2, малюнки -2 , хрень -2 , естетика -2 , БМВ, JОЈО, завтра, інтерес, книги, пензлик, концепти, стрічка із зображеннями, багато-багато фотографій, ведмідь, манікюрчик допомагає підібрати, не стикався, шпалери, нічого, пейнтбол, пошук, піаніст, добірка, корисне, порожнеча, рецепт, проекти, звалище фотографій, подія, трест, таке, соціальний майданчик, туторіали, зручності і графічний контент усього світу, щось творче, я натурал».

За наведеними реакціями стає зрозумілим, що ця соціальна мережа у більшості інформантів або не викликає ніяких реакцій, або іï не знають зовсім (реакції щзо ц̧е?, не знаю, не стикався). Однак деякі інформанти визначають іiі подібно мережі Інстаграм: багато-багато фотографій, звалище фотографій, зручності і графічний контент усього світу, стрічка із зображеннями. Це арт колекція зображень і краса, естетика; там є рецепти, проекти i пензлики. Негативних реакцій зустрілося на цю соціальну мережу досить мало: нічого, хрень, порожнеча.

\section{Висновки}

У цілому, проведений асоціативний експеримент показав, що інформаційна, комунікативна й функціональна складова Глобальної мережі найбільше актуалізована в мовній свідомості інформантів учасників освітнього процесу.

Отримані асоціації показують також, що інформаційна функція соціальних медіа виходить на перший план. Вони виступають як ЗМІ або як певна їх альтернатива, і вони безпосередньо пов〉язані зі сферою ІКТ. 
I практично всі сервіси соціальних медіа сприймаються неоднозначно - одержувані реакції мають як позитивну, так i негативну конотацію.

Цікаво, що освітня складова соціальних медіа практично в мовній свідомості наших реципієнтів не відзначилася (зустрічаються лише поодинокі реакції), що побічно вказує на те, що їх використання в освітньому процесі ще не $\epsilon$ інституціональною практикою.

У даній роботі ми навели лише змішаний аналіз сприйняття соціальних медіа від двох цільових груп - студентів і викладачів університетів. Надалі планується також порівняти асоціативні поля, окремо зібрані від викладачів і студентів, і проаналізувати подібності та відмінності в сприйнятті цих технологій основними стейкхолдерами цієї інституційної практики.

Зауважимо, що асоціативний експеримент здійснювався в режимі онлайн. Планується також проведення аналогічного експерименту i в офлайні, щоб перевірити валідність його результатів і зрозуміти, чи впливає спосіб проведення (онлайн і оффлайн) і тип використовуваної методології (вільне володіння i спрямований асоціативний експеримент) на одержувані дані, що сприятиме вдосконаленню, на нашу думку, такого нового напряму в мовознавстві 21 століття як психолінгвістика 2.0, який вивчає психологічні та лінгвістичні аспекти мовної діяльності людини в соціальних медіа, а також соціальні та психологічні аспекти використання мови в процесах мовленнєвої комунікації за допомогою платформ і сервісів веб 2.0.

Підводячи підсумок сказаному, підкреслимо, що дослідження має міждисциплінарний характер, перебуваючи на перехресті психолінгвістики 2.0 і освіти 2.0, що сприяє кращому розумінню поліпарадигмального шляху розвитку гуманітарного знання під впливом технологій у цілому.

\section{Література}

Горошко, Е.И. (2005). Проблема проведения свободного ассоциативного эксперимента. Известия Волгоградского государственного педагогического университета, 3, 53-61.

Леонтьев, А.А. (1989). Психолингвистика. Тенденциии развития психологической науки. Москва. 
Леонтьев, А.А. (2003). Основы психолингвистики (3-е изд.). Москва: Смысл; СПб.: Лань.

Образование 2.0: как заинтересовать ученика в 21 веке? (2017). Режим доступу: https://nv.ua/ukraine/goglobal/obrazovanie-2-0-kak-zainteresovat-uchenika-v-21veke-756793.html

Уфимцева, Н.В. (Ред.). (2000). Языковое сознание и образ мира. Москва: Институт языкознания РАН.

Altmann, G. (Ed.). (2002). Psycholinguistics: critical concepts in psychology (Vols. 1-6). London and New York: Routledge. Taylor \& Francis Group.

Davis, L. (2018). The Impact of Social Media in Education: Student Engagement Tactics. Retrieved from https:/www.schoology.com/blog/impact-social-mediaeducation-student-engagement-tactics

Demirdag, S. (2016). Examining the computer attitudes and Internet attitudes of substitute teachers: self-confidence towards ICT. International journal of psychoeducational sciences, 5(2), 87-98.

Evans, Rh., \& Nygaard, C. (2019). E-learning 1.0, 2.0, and 3.0 in Higher Education (Learning in Higher Education series). Libri Publishing, Amsterdam.

Harley, T. (2005). The psychology of language. From data to theory ( $2^{\text {nd }}$ ed.). Hove and New York: Taylor \& Francis Group.

How tech and social media have changed the face of education. (2018). Independent News for International Students. Retrieved from https://www.studyinternational. com/news/tech-social-media-changed-face-education/

Hussain, F. (2012). E-Learning 3.0 = E-Learning 2.0 + Web 3.0. LIADIS International Conference on Cognition and Exploratory Learning in Digital Age (CELDA, 2012) (pp. 11-18). Celda.

Internet. Statistics and Market Data about the Internet. (2019). Retrieved from https:// www.statista.com/markets/424/internet/

Internet World Stats. (2019). Usage and Population Statistics. Retrieved from https:// www.internetworldstats.com/stats.htm

Jones, V., Jo, J.H., \& Philippe, A.M. (2007). Future schools and how technology can be used to support Millennial and Generation-Z Students. ICUT 2007, 1st International Conference of Ubiquitous Information Technology (pp. 886-891).

Keats, D., \& Schmidt, J. (2007). The genesis and emergence of Education 3.0 in higher education and its potential for Africa. First Monday, 12(3). https://doi. org/10.5210/fm.v12i3.1625

Liu, I.F., \& Ko, H.W. (2019). Roles of paper-based reading ability and ICT-related skills in online reading performance. Reading and Writing, 32(4), 1037-1059. https://doi.org/10.1007/s11145-018-9892-z

Perrin, A., \& Anderson, M. (2019). Share of U.S. adults using social media, including Facebook, is mostly unchanged since 2018. Pew Research Center. Retrieved from https:/www.pewresearch.org/fact-tank/2019/04/10/share-of-u-s-adults-usingsocial-media-including-facebook-is-mostly-unchanged-since-2018/

Preparing 21st century students for a global society. (2012). Washington, DC: National Education Association.

Tîrziua, A.M, \& Vrabie, C., (2015). Education 2.0: E-Learning Methods. Social and Behavioral Sciences, 186, 376-380. https://doi.org/10.1016/j.sbspro.2015.04.213

Traxler, M.I., \& Gernsbacher, M.A. (Eds.). (2006). Handbook of psycholinguistics $\left(2^{\text {nd }}\right.$ ed. $)$. New York: Academic Press.

Trevisan, P., \& Garcia, A. (2019). Systematic functional grammar as a tool for experimental stimulus design: new applicable horizons in psycholinguistics 
and neurolinguistics. Language sciences, 75, 35-46. https://doi.org/10.1016/j. langsci.2019.101237

\section{References}

Goroshko, O.I. (2005). Problema provedeniya svobodnogo assotsiativnogo eksperimenta [The problem of conducting a free associative experiment]. Izvestiya Volgogradskogo gosudarstvennogo pedagogicheskogo universiteta - Izvestiya of Volgograd State Pedagogical University, 3, 53-61 [in Russian].

Leontyev, A.A. (1989). Psikholingvistika [Psycholinguistics]. Tendentsii razvitiya psikhologicheskoy nauki [Trends in the Development of Psychological Science]. Moscow [in Russian].

Leontyev, A.A. (2003). Osnovy psikholingvistiki [Fundamentals of psycholinguistics] (3nd ed.). Moscow: Smysl; Saint Petersburg: Lan [in Russian].

Obrazovaniye 2.0: kak zainteresovat uchenika v 21 veke? [Education 2.0: how to rouse a student's interest in the 21st century?]. (2017). Retrieved from https://nv.ua/ ukraine/goglobal/obrazovanie-2-0-kak-zainteresovat-uchenika-v-21-veke-756793. html [in Russian].

Ufimtseva, N.V. (Ed.). (2000). Yazykovoye soznaniye $i$ obraz mira [Linguistic consciousness and the image of the world]. Moscow: Institute of linguistics Russian Academy of Sciences [in Russian].

Altmann, G. (Ed.). (2002). Psycholinguistics: critical concepts in psychology (Vols. 1-6). London and New York: Routledge. Taylor \& Francis Group.

Davis, L. (2018). The Impact of Social Media in Education: Student Engagement Tactics. Retrieved from https://www.schoology.com/blog/impact-social-mediaeducation-student-engagement-tactics

Demirdag, S. (2016). Examining the computer attitudes and Internet attitudes of substitute teachers: self-confidence towards ICT. International journal of psychoeducational sciences, 5(2), 87-98.

Evans, Rh., \& Nygaard, C. (2019). E-learning 1.0, 2.0, and 3.0 in Higher Education (Learning in Higher Education series). Libri Publishing, Amsterdam.

Harley, T. (2005). The psychology of language. From data to theory ( $2^{\text {nd }}$ ed.). Hove and New York: Taylor \& Francis Group.

How tech and social media have changed the face of education. (2018). Independent News for International Students. Retrieved from https://www.studyinternational. $\mathrm{com} /$ news/tech-social-media-changed-face-education/

Hussain, F. (2012). E-Learning 3.0 = E-Learning 2.0 + Web 3.0. LIADIS International Conference on Cognition and Exploratory Learning in Digital Age (CELDA, 2012) (pp. 11-18). Celda.

Internet. Statistics and Market Data about the Internet. (2019). Retrieved from https:// www.statista.com/markets/424/internet/

Internet World Stats. (2019). Usage and Population Statistics. Retrieved from https:// www.internetworldstats.com/stats.htm

Jones, V., Jo, J.H., \& Philippe, A.M. (2007). Future schools and how technology can be used to support Millennial and Generation-Z Students. ICUT 2007, 1st International Conference of Ubiquitous Information Technology (pp. 886-891).

Keats, D., \& Schmidt, J. (2007). The genesis and emergence of Education 3.0 in higher education and its potential for Africa. First Monday, 12(3). https://doi. org/10.5210/fm.v12i3.1625 
Liu, I.F., \& Ko, H.W. (2019). Roles of paper-based reading ability and ICT-related skills in online reading performance. Reading and Writing, 32(4), 1037-1059. https://doi.org/10.1007/s11145-018-9892-z

Perrin, A., \& Anderson, M. (2019). Share of U.S. adults using social media, including Facebook, is mostly unchanged since 2018. Pew Research Center. Retrieved from https://www.pewresearch.org/fact-tank/2019/04/10/share-of-u-s-adults-usingsocial-media-including-facebook-is-mostly-unchanged-since-2018/

Preparing 21st century students for a global society. (2012). Washington, DC: National Education Association.

Tîrziua, A.M, \& Vrabie, C., (2015). Education 2.0: E-Learning Methods. Social and Behavioral Sciences, 186, 376-380. https://doi.org/10.1016/j.sbspro.2015.04.213

Traxler, M.I., \& Gernsbacher, M.A. (Eds.). (2006). Handbook of psycholinguistics $\left(2^{\text {nd }}\right.$ ed.). New York: Academic Press.

Trevisan, P., \& Garcia, A. (2019). Systematic functional grammar as a tool for experimental stimulus design: new applicable horizons in psycholinguistics and neurolinguistics. Language sciences, 75, 35-46. https://doi.org/10.1016/j. langsci.2019.101237

\section{АНОТАЦІЯ}

Вступ. У даній роботі представлені результати дослідження впливу нових інформаційно-комунікативних технологій, а саме інтернет-технологій соціального веба, на мовну свідомість в освітньому середовищі. Даний термін має на увазі певну концепцію розвитку Глобальної павутини, коли основне функціональне завдання веб-сервісу спрямоване на підтримку взаємодії між користувачами мережі.

Методи дослідження. В якості основного способу дослідження було обрано метод вільного й спрямованого асоціативного експерименту, який дозволяє найбільш точно виявити значення поняття, що саме стоїть за цим словом у мовній свідомості людини. Були визначені асоціативні ряди на ряд понять найбільш популярних сервісів соціального вебу та інтернет-технологій (Інтернет, Інстаграм, соціальні медіа, комунікація, Твіттер, Телеграм, ВатсАп, Ютуб, Пінтрест, Гугл, Селфі, Фейсбук).

Результати. Проведений асоціативний експеримент показав, що в мовній свідомості учасників освітнього процесу найбільше актуалізовані інформаційна, комунікативна й функціональна складові Глобальної мережі. Практично всі сервіси соціальних медіа мають як позитивну, так і негативну конотацію. Освітня складова сочіальних медіа в мовній свідомості реципієнтів практично не відзначилася, що побічно вказує на те, що їх використання в освітньому процесі ще не є інституціональною практикою.

Висновки. Результати дослідження сприятимуть розвитку нового напряму в сучасній лінгвістиці - психолінгвістики 2.0, яка вивчає психологічні та лінгвістичні аспекти мовної діяльності людини в соціальних медіа, а також сочіальні та психологічні аспекти використання мови в процесах мовленнєвої комунікації за допомогою платформ і сервісів веб 2.0, індивідуальної мислемовної діяльності. Дослідження має міждисциплінарний характер, перебуваючи на 
перехресті психолінгвістики 2.0 і освіти 2.0, що сприяє кращому розумінню поліпарадигмального шляху розвитку гуманітарного знання під впливом технологій у цілому.

Ключові слова: освіта 2.0, психолінгвістика 2.0, сочіальний веб, інтернеттехнології, вільний асоціативний експеримент.

Горошко Елена, Полякова Татьяна. Образование 2.0: психолингвистический анализ

\section{АННОТАЦИЯ}

Вступление. В данной работе представлены результаты исследования влияния новых информационно-коммуникативных технологий, а именно интернеттехнологий социального веба, на языковое сознание в образовательной среде. Данный термин подразумевает определенную концепцию развития Глобальной паутины, когда основная функциональная задача веб-сервиса направлена на поддержание взаимодействия между пользователями сети.

Методы исследования. В качестве основного метода исследования был выбран метод свободного и направленного ассоциативного эксперимента, позволяющий наиболее точно выявить значение слова, что именно стоит за этим словом в языковом сознании человека. Были определены ассоциативные ряды на ряд понятий - наиболее популярных сервисов социального веба и интернет-технологий (Интернет, Инстаграм, социальные медиа, коммуникация, Твиттер, Телеграм, ВатсАп, Ютуб, Пинтрест, Гугл, селфи, Фейсбук).

Результаты. Проведенный ассоциативный эксперимент показал, что в языковом сознании участников образовательного процесса более всего актуализированы информационная, коммуникативная и функциональная составляющая Глобальной сети. Практически все сервисы социальных медиа имеют как положительную, так и негативную коннотацию. Образовательная составляющая социальных медиа в языковом сознании реципиентов практически не запечатлена, что косвенно указывает на то, что их использование в образовательном процессе еще не является институциональной практикой.

Выводы. Результаты исследования будут способствовать развитию нового направления в современной лингвистике - психолингвистики 2.0, изучающей психологические и лингвистические аспекты речевой деятельности человека в социальных медиа, социальные и психологические аспекты использования языка в процессах речевой коммуникации с помощью платформ и сервисов веб 2.0, индивидуальной речемыслительной деятельности. Исследование имеет междисииплинарный характер, находясь на перекрестке психолингвистики 2.0. и образования 2.0, что способствует лучшему пониманию полипарадигмального пути развития гуманитарного знания под воздействием технологий в целом.

Ключевые слова: образование 2.0, психолингвистика 2.0, сочиальный веб, интернет-технологии, свободный ассоциативный эксперимент. 